\title{
Financial Leverage, Growth and Investment Efficiency
}

\author{
Xinxin Liu \\ Beijing Jiaotong University, China
}

Keywords: financial leverage; growth; the efficiency of investment

\begin{abstract}
This paper studied the relationship among financial leverage, growth and the investment efficiency, using the data of listed companies during 2013-2016. The study found that insufficient investment phenomenon is more common. Instead of linearity, the relationship between financial leverage and investment efficiency is inverted $U$ shape; Taking the different growth of company into consideration, it found that in the high growth firms, the role of debt is mainly reflected in the promotion to insufficient investment, for low growth firms the effect is mainly manifested in the inhibition to overinvestment. These findings will provide some guidance for the company's financing and investment.
\end{abstract}

\section{Introduction}

With the development of the supply side reform, "de leveraging" is one of the key tasks of structural reform in China. In the process of reform, the adjustment of corporate financing structure will affect the investment situation. So the study of the relationship between debt and investment efficiency is crucial. However, among the domestic literatures, documents that measure investment efficiency and its influencing factors are still deficient. Besides, there are obvious differences in the growth of Listed Companies, but studies are relatively insufficient. Therefore, based on the data of Listed Companies in recent four years, this paper tries to explore the impact of company growth level and financial leverage on corporate investment efficiency

\section{Literature Review}

Reasons for Inefficiency Investment. Agent Theory. The separation of management and ownership leads to the existence of agency conflicts between managers and shareholders [1]; when the ownership is dispersed, it is hard for shareholders to effectively supervise managers, enterprise managers tend to use excess cash to invest non profitable projects. [2]. Under the concentration, the controlling shareholders can rely on their control-power to seek private interests in a lawful way [3]. Conflicts with minority shareholders will be prominent. Therefore, both of them are likely to overinvest. Shareholders take value maximize as the chief goal, but creditors are inclined to pay more attention to the security of the principal and interest. Debtors cannot fully supervise the shareholders and this will lead to inefficient investment of shareholders

Theory of Information Asymmetry. In making decisions, the shareholders tend to conceal risky to creditors so they can invest in high risk-return projects. In order to prevent the moral risk, capital providers often ask for a higher risk premium by raising interest rates, increase restrictions and other means. What they do generally cause the cost of external financing is higher than the internal and the insufficient investment. Besides, the adverse selection makes it impossible to make a reasonable estimation. Overestimating stock value will lead to excessive investment and underestimating will lead to underinvestment.

\subsection{Research on the Relationship between Financial Leverage and Investment Efficiency.}

Financial leverage is an important factor influencing investment [4]. The study of Lang found that debt would inhibit the capital expenditure. Yue Xuhua conducted an empirical test in Chinese market and the result was similar. Wang Luping found that the negative correlation in the low growth listed companies was more obvious [5]. However, there is also a small part of the study 
indicating there is no significant relationship between the two. Zhu Jing found there is no significant negative correlation between debt and the loss of overinvestment efficiency.

\subsection{Research on the Relationship between Growth and Investment Efficiency.}

Growth ability reflects the future growth potential and market value of companies, it has a positive correlation with investment level. High growth enterprises have more investment opportunities and are easy to overinvest. But at the same time, they are also severely constrained by financing [6]. The rise of debt level often limits the providers' further investment and causes the company's underinvestment. Low growing company often have large amounts of capital and lack of good investment channels, which is easy to implement excessive investment, and hard debt constraint can inhibit the over investment to a certain extent [7].

\section{Research Hypothesis}

When debt level is low, it can effectively alleviate the financing constraints and restrain insufficient investment; However, with the continuous improvement of debt, the alleviation effect of debt financing tends to weaken. When level is too high, it will stimulate excessive investment and reduce investment efficiency. Based on this, we put forward the first hypothesis:

H1: there is an inverted $U$ relationship between debt leverage and enterprise investment efficiency.

The high growth enterprises have more investment opportunities, but the pressure of repayment formed will force managers to give up some projects with positive NPV, so the increase of debt may cause the shortage of investment. But for the low growth enterprises, the free cash flow is abundant while better investment opportunities are inadequate. So they are easy to fall into excessive investment. Based on the above analysis, second hypotheses are put forward.

$\mathrm{H} 2$ : for high growth companies, the impact of financial leverage on investment efficiency is more related to the excess of investment, while the impact on low growth firms is more underinvestment

\section{Research Design}

\subsection{Data Sources.}

This paper selected A-share listed companies in Shanghai and Shenzhen from 2013 to 2016 as samples and excluded them according to the following principles: (1) Financial insurance companies and ST companies. (2) Incomplete data and companies with missing data. (3) Newly listed companies. All the data came from the CSMAR database, and the data processing used the statistical software Stata 12.0. After screening, the total number of sample companies for the final study was 7650 .

\subsection{Variables Definition.}

This paper mainly uses Richardson's (2006)[8] method of calculating inefficient investment to measure over- investment.

INTt $=\mathbf{a}+\mathbf{a}_{\mathbf{0}}$ Growth $+\mathbf{a}_{\mathbf{1}}$ Levt- $1+\mathbf{a}_{\mathbf{2}}$ Casht- $1+\mathbf{a}_{\mathbf{3}}$ Aget $-1+\mathbf{a}_{\mathbf{4}}$ Sizet-1 $+\mathbf{a}_{\mathbf{5}}$ Returnt $-1+\mathbf{a}_{\mathbf{6}}$ INVt-1 $+\Sigma$ Year $+\Sigma$ IND $+\varepsilon$

Model Establishment

$\mathrm{H} 1$ :

$\mathrm{E}=\mathrm{b} 0+\mathrm{b} 1 \mathrm{LEV}+\mathrm{b} 2$ lev2 $+\mathrm{b} 3 \mathrm{CF}+\mathrm{b} 4 \mathrm{TQ}+\mathrm{b} 5 \mathrm{Occupy}+\Sigma$ Ind $+\sum$ Year $+\varepsilon$

H2: OverINVt/UnderINVt $=\mathrm{c}+\mathrm{c} 0 \mathrm{LEV}+\mathrm{c} 1 \mathrm{LEV} 2+\mathrm{c} 2 \mathrm{CF}+\mathrm{c} 3 \mathrm{TQ}+\mathrm{c} 4 \mathrm{Occupy}+\Sigma \mathrm{Ind}+\Sigma$ Year $+\varepsilon$

Descriptive Statistics. Full Sample Descriptive Statistics.

The minimum and maximum values of the efficiency were -0.176633 and 0.24721 , indicating the difference of enterprises was large. The average Lev was 0.4388971 , indicating that leverage ratio is generally high. The sample of overinvestment accounted for about $62 \%$, same with the expection.

Analysis of the regression results between EFF and financial leverage. We can see that when Lev 
was in low range, e gradually ran to 0,meaning the investment efficiency was increasing, but after reaching a certain range, e began to go up from 0 , and the investment efficiency began to decrease, which showed that the efficiency was not a simple linear relationship with the debt. The (2) showed that when the level of debt was low, with the increase of debt, the efficiency of underinvestment was relieved. When it reached a high level of debt, the enterprise tended to overinvest, but with continuous increasing of debt, the efficiency fell from the beginning.

Table 1. The minimum and maximum values of the efficiency

\begin{tabular}{|c|c|c|c|c|c|}
\hline Variable & Obs & Mean & Std. Dev. & Min & Max \\
\hline e1 & 7648 & $-1.14 \mathrm{E}-10$ & 0.0429995 & -0.176633 & 0.24721 \\
\hline e(|e1|) & 7648 & 0.0294043 & 0.0313725 & $3.90 \mathrm{E}-06$ & 0.24721 \\
\hline lev & 7648 & 0.4388971 & 0.2131861 & 0.007969 & 1.22613 \\
\hline lev2 & 7648 & 0.2380731 & 0.201723 & 0.000064 & 1.50339 \\
\hline occupy & 7648 & 0.0435315 & 0.0703105 & -0.174205 & 0.245478 \\
\hline cf & 7648 & 0.0158937 & 0.022682 & 0.000134 & 0.134796 \\
\hline tq & 7648 & 2.38683 & 2.167397 & 0.194451 & 13.0194 \\
\hline capex & 7648 & $3.14 \mathrm{E}+08$ & $1.06 \mathrm{E}+09$ & $-8.50 \mathrm{E}+08$ & $8.10 \mathrm{E}+09$ \\
\hline overinv & 2901 & 0.0387597 & 0.0428451 & 0.000021 & 0.24721 \\
\hline underinv & 4747 & -0.023687 & 0.0194412 & -0.176633 & $-3.90 \mathrm{E}-06$ \\
\hline
\end{tabular}

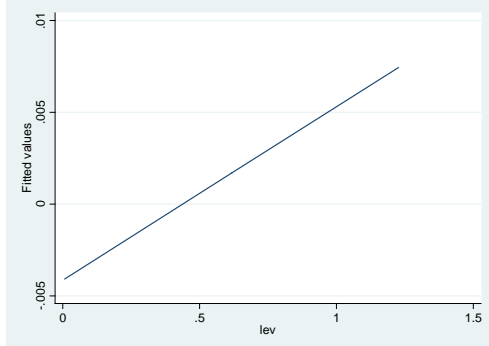

(1) full sample eff and lev

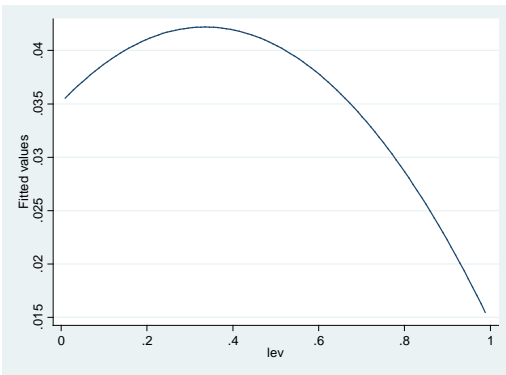

(3) Overinvest

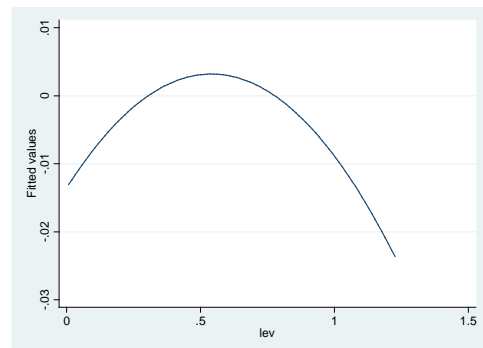

(2) full sample eff and LEV^2

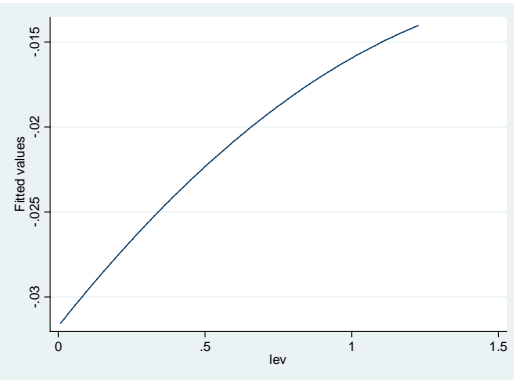

(4) insufficient investment

Fig. 1. Curves of different variables

Table 2. The efficiency of underinvestment

\begin{tabular}{|c|c|c|c|c|c|c|}
\hline & & Coef. & Std. Err. & $\mathbf{t}$ & $\mathbf{P}>\mathbf{t}$ & [95\% Conf. Interval] \\
\hline \multirow{2}{*}{$\begin{array}{c}\text { Under } \\
\text { inv }\end{array}$} & lev & 0.0167589 & 0.0052221 & 3.21 & 0.001 & $(0.0065211,0.0269966)$ \\
\cline { 2 - 7 } & lev2 & -0.0092513 & 0.0054061 & -1.71 & 0.087 & $(-0.0198498,0.0013472)$ \\
\hline \multirow{2}{*}{$\begin{array}{c}\text { Over } \\
\text { inv }\end{array}$} & lev & 0.0630034 & 0.0170208 & 3.7 & 0 & $(0.0296292,0.0963777)$ \\
\cline { 2 - 7 } & lev2 & -0.0660158 & 0.0178187 & 3.7 & 0 & $\begin{array}{c}(-0.1009546, \\
-0.0310771)\end{array}$ \\
\hline
\end{tabular}

The sample was divided into two types: under and over investment. The results in the second were less obvious than that in underinvestment. They supported the classification mechanism of the 
effect on insufficient and excessive investment. The excessive debt leverage is the radical financial planning, being not conducive to the efficiency of investment. However, in underinvestment enterprises, the increase of debt leverage is positive financial planning for investment efficiency.

Growth and investment efficiency.

Table 3. Growth efficiency

\begin{tabular}{|c|c|c|c|c|}
\hline lev & Mean & Std. Dev. & Min & Max \\
\hline High growth & 0.365428 & 0.1839542 & 0.007969 & 1.22613 \\
\hline Low growth & 0.6452546 & 0.1425336 & 0.169338 & 0.978569 \\
\hline
\end{tabular}

Table 4. Investment efficiency

\begin{tabular}{|c|c|c|c|c|c|}
\hline \multicolumn{2}{|c|}{} & \multicolumn{2}{c|}{ High growth(5640) } & \multicolumn{2}{c|}{ Low growth(2008) } \\
\cline { 3 - 6 } & overinv & underinv & overinv & underinv \\
\hline \multirow{2}{*}{ lev } & coff & 0.0598354 & 0.0227689 & 0.0507596 & 0.0061257 \\
\hline \multirow{2}{*}{ lev2 } & $\mathbf{P}>|\mathbf{t}|$ & 0.008 & 0 & 0.468 & 0.742 \\
\cline { 2 - 6 } & coff & -0.0582515 & -0.0200187 & -0.0375803 & -0.09 \\
\hline \multicolumn{2}{|c|}{ Proportion } & $38.00 \%$ & $62.00 \%$ & $37.75 \%$ & 0.932 \\
\hline
\end{tabular}

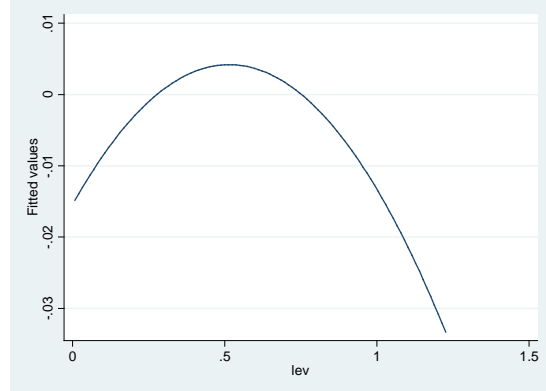

HG

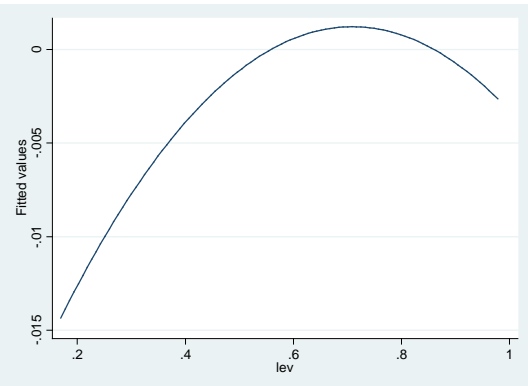

LG

Fig. 2. Curves HG and LG

From table 4, we know that high growth firms occupied the most, and from p, the impact of debt on efficiency was more significant in the high growth firms. In terms of internal comparison, for LG, debt had more obvious effect on excessive investment. From the chart, in the high growth firms, the main role of debt was reflected in the promotion of insufficient investment. When the ratio of debt was high, the efficiency of underinvest obviously reduced; In addition, the ratio of debt was high in the low growth firms, so the effect was mainly manifested in the inhibition to overinvestment

\section{Robustness Test}

Firstly, the net asset return was used to measure the growth opportunity. Secondly, market net rate $(\mathrm{P} / \mathrm{B})$ was the substitute index of the growth of the company. The average value after removing the abnormal value was the standard. All the results were still the same as the main test.

\section{Conclusion}

Through empirical analysis, we find that the nonlinear relationship between investment efficiency and liabilities is the inverted $U$ shape. In the certain range of lower debt ratio, promotion of debt will reduce the shortage of investment and promote the efficiency. But when ratio is high, the continuous enhancement will give rise to the over investment. In addition, different growth means different role of liabilities. For high-growth companies, financial leverage will mainly promote the lack of investment, but in low growth, it plays the role to prohibit excessive 
investment.

\section{References}

[1] R M Stulz. Managerial Discretion and Optimal Financing Policies, J. Journal of Financial Econimics, 1990, pp.3-27.

[2] Ma Lijun and Wu Tao, financial leverage and enterprise investment relationship discussion, J. Economic forum, 2010, pp. 175 - 177.

[3] Yao Mingan and Kong Ying, The impact of financial leverage on Enterprise Investment, J. Accounting research, 2008, pp. $33-40$.

[4] Jensen, M.C. Agency Cost of Free Cash Flow, Corporate Finance, and Takeover. J. American Economic Review, 1986, pp.323-329.

[5] Wang Luping and Mao Weiping, Financial leverage, investment opportunities and corporate investment behavior -- evidence based on Panel Data of manufacturing listed companies, J. Management review, 2010, pp. 99 - 110.

[6] Ma Hong and Wang Yuanyue, does the deleveraging increase the investment efficiency of the enterprise? J. China Securities newspaper, 2017, pp. 13 - 20.

[7] Dou Wei and Li Guangliang, Financial leverage, growth characteristics and corporate investment behavior, J. China management information, 2015, pp. $11-15$.

[8] Richardson. S, Over-investment of Free Cash Flow, J. Review of Accounting Studies, 2006, pp.159-189. 